\title{
AT TAAJIRR
}

Vol. 1, No. 1, (2019)

ISSN : 2685-435X

Juli - Desember

E-ISSN :

\section{HUKUM UTILITAS DALAM EKONOMI ISLAM \\ Agus Tomi \\ Bank Syariah Mandiri Bandar Lampung}

Abstract

Islamic banks are financial institutions that have a large influence in providing funds for the community, especially for the development of the life of a business entity. This institution plays an important role in collecting funds from the community and distributing it again to the community. Islamic banks channel excessive money to be used by other parties in need by providing assistance in the form of loans or financing, both to companies and individuals.

Based on the description above, the author tries to find a description of the extent to which the concept of satisfaction (utility) in Islamic economics is compared to the concept of satisfaction (utility) in a conventional economy.

Satisfaction in Islamic economics has a more comprehensive view and meaning when compared to the concept of conventional satisfaction, where in Islamic economics satisfaction is not only to meet the needs and desires to achieve mutual benefit (community welfare) but lead to obedience as God's creatures based on values Islamic. Whereas in the conventional view that satisfaction is every individual can always determine which condition is preferred between two conditions or more (completness) regardless of the health and harm. It is clear that man's desire to accumulate wealth, but also his need for preparation in the future, thus that if the spirit of always wanting more this will lead to greed and the pursuit of personal lust, then this views wealth as the "greatest test".

Keyword: Hukum Utilitas, Ekonomi Islam, Conventional, Financial Institutions

\section{LATAR BELAKANG}

Manusia sebagai mahluk hidup yang selalu membutuhkan sarana dan kebutuhan pokok untuk dapat memenuhi kebutuhan dan keinginan, tentu saja dalam realitanya dihadapkan dengan pilihan untuk memperoleh nilai kepuasan tertentu sehingga tercipatnya kemaslahatan untuk dirinya sendiri maupun orang lain.

Teori pilihan (theory of choice) dalam ilmu ekonomi dimulai dengan menjelaskan preferensi (pilihan) seseorang. Preferensi ini meliputi pilihan dari yang sederhana sampai yang paling kompleks untuk menunjukkan bagaimana seseorang dapat merasakan atau menikmati segala sesuatu yang ia lakukan. Hanya saja yang perlu diperhatikan adalah faktor keseimbangan antara kebutuhan, preferensi dan ketersediaan sumber daya yang dimiliki. Salah satu model preferensi individu adalah konsep utilitas (utility). ${ }^{1}$

Dalam ekonomi konvensional, konsumen diasumsikan selalu bertujuan untuk memperoleh kepuasan (utility) dalam kegiatan konsumsinya. Sehingga, motif memperoleh kepuasan itu membawa pada perbedaan keputusan pengalokasian sumber daya. Hal itu semua akibat dari tingkat kebutuhan seseorang yang berbeda. Sedangkan dalam perspektif Islam, kebutuhan ditentukan oleh konsep maslahah yang disesuaikan dengan maqasid alShariah. Asumsi ini berangkat dari realitas bahwa pembahasan konsep kebutuhan dalam Islam tidak dapat dipisahkan dari kajian perilaku konsumen dari kerangka maqasid al-Shariah. ${ }^{2}$

\footnotetext{
1 Joko Susilo, Analisis Maslahah Pemikiran Al-Ghozali dan Relevansinya Terhadap Ekonomi Kontemporer, Tesis Ekonomi Islam, IAIN Sunan Ampel, 2001 Hal 2

2 Ibid Hal. 3
} 


\section{AT TAAJIIR}

Vol. 1, No. 1, (2019)

ISSN : 2685-435X

Juli - Desember

E-ISSN :

Hal serupa juga disampaikan oleh Yusuf Qordhowi 2009 ; Kegiatan Ekonomi Islam berorientasi pada kesejahteraan bersama (maslahah) sedangkan konvensional lebih pada kepuasan idividu. ${ }^{3}$

Berdasarkan uraian di atas, maka penulis mencoba untuk mencari gambaran sejauh mana konsep kepuasan (utility) dalam ekonomi Islam dibandingkan dengan konsep kepuasan (utility) dalam ekonomi konvensional.

\section{PEMBAHASAN}

\section{Economic man vs Islamic Man}

\section{Economic Man}

Di dalam buku Defining Islamic Man, 2006 Abdul Karim menuliskan bahwa dalam keseluruhan proses sistem ekonomi konvensional tidak ada konsep ketuhanan, nilai moral, hari pembalasan, atau saling menolong sesama. Seluruhnya hanya untuk pemenuhan kepuasan individu dan tidak ada tempat untuk nilai-nilai moral. Pelaku ekonomi itu lebih pada kepentingan pribadi tidak pernah memikirkan kepuasan orang lain. Economic man hanya berpusat pada dirinya dan kepuasan pribadi dirinya, tanpa pernah memikirkan di luar dari kepuasan dirinya. Pendekatan yang dilakukan economic man benar-benar materialistik dan mereka selalu menghitung keuntungan atau kerugiannya dalam konteks keuangan semata. Tujuan utama mereka adalah untuk mendapatkan keuntungan maksimal dalam kehidupan dunia dan tidak memiliki konsep tentang kehidupan sesudah kehidupan di dunia. Tipe pemikiran ini secara alami akan membatasi kehidupan mereka hanya untuk hari ini dan tidak ada konsep keuntungan jangka panjang. ${ }^{4}$

\section{Islamic Man}

Karakteristik Islamic man dapat dilihat dari kualitas momieen di dalam Al-Qur'an dan Hadits, dimana sedikitnya terdapat lebih dari enam puluh kualitas. Kata "amal sholeh" digunakan untuk aktivitas-aktivitas tersebut. Amal sholeh merupakan berbagai aktivitas yang menghasilkan keuntungan bagi orang lain, atau menghasilkan kesejahteraan di masyarakat, atau sebaliknya mengurangi keburukan (fasad) dalam masyarakat. Beberapa karakteristik Islamic man dipaparkan berikut ini. ${ }^{5}$

1. Iman

2. Berorientasi kepada ridho Allah

3. Khawatir akan hari akhirat

4. Saling menolong

5. Tidak mengharapkan balasan

6. Mengharamkan riba

7. Infaq

8. Konsep halal dan haram

\footnotetext{
3 Yusuf Al Qordhawi: Ekonomi Islam Nilai dan Akhlak, YaPEIM, 2009 Kuala Lumpur

${ }^{4}$ Abdul Karim : Defining Islamic Man, Daily Dawn, June 092006

${ }^{5}$ Farooq Aziz, H Abbas, M Aqil Bhutto SA : Economic Man Vs Islamic Man, Interdisci;inary Jounal Of Contemporary Reserch In Business, Vol 3 No. 2. 2011
} 


\section{AT TAAJIIR}

Vol. 1, No. 1, (2019)

ISSN : 2685-435X

Juli - Desember

E-ISSN :

\section{Peduli terhadap orang miskin}

\section{Perbandingan Antara Economic Man dan Islamic Man ${ }^{6}$}

Berdasarkan pemaparan di atas dapat dilihat perbedaan yang jauh antara kedua konsep tersebut. Beberapa perbedaan tersebut antara lain adalah :

Konsep terbatas dan luas

Konsep economic man terbatas, dimana manusia hanya tergantung dunia materialistik. Sedangkan Islamic man memiliki cakupan yang lebih luas, yang tidak hanya melihat kehidupan sebatas dunia saja tetapi juga kehidupan setelahnya yang merupakan kehidupan sebenarnya dan kekal.

Level binatang dan manusia

Konsep economic man hanya sebatas tingkat binatang, dimana dibatasi oleh kepuasan maksimal, keuntungan atau kebebasan, tanpa nilai-nilai moral. Sedangkan Islamic man memiliki konsep yang lebih baik dimana mengacu pada nilai-nilai moral yang merepresentasikan level manusia dalam kehidupan.

Egoisme dan Tolong menolong

Keuntungan individu merupakan keterbatasan pada cara berfikir economic man, meraka tidak dapat melakukan lebih dari itu. Sedangkan tujuan kehidupan Islamic man adalah untuk menolong/melayani orang lain untuk mendapat ridho Allah.

Jalan hidup terbuka dan terbatas

Economic man sangat bebas untuk melakukan segalanya mengacu kepada peraturan negara. Tidak ada yang dapat membatasinya. Sedangkan Islamic man mengacu kepada hukum agama sebagaimana mengacu kepada hukum negara.

Mementingkan hari ini atau masa depan

Economic man hanya meyakini keuntungan hari ini untuk hari ini dan dia tidak mempersiapkannya untuk hari esok. Sedangkan Islamic man selalu menjadikan keuntungan hari esok (hari akhirat) sebagai acuan. ${ }^{7}$

\section{Utilitas dan Teori Konsumsi Islam}

\section{Fungsi Kesejahteraan dan Utilitas menurut Imam Al-Ghazali}

Imam Al-ghazali, konsep maslahat, atau kesejahteraan sosial atau utilitas ("kebaikan bersama") merupakan konsep yang mencakup semua urusan manusia, baik urusan ekonomi maupun urusan lainnya, dan yang membuat kaitan yang erat antara individu dengan masyarakat. Dalam meningkatkan kesejahteraan sosial, Imam Al-Ghazali mengelompokkan dan mengidentifikasi semua maslah baik yang berupa masalih (utilitas, manfaat) maupun mafasid (disutilitas, kerusakan) dalam meningkatkan kesejahteraan sosial. ${ }^{8}$

\footnotetext{
6 Ibid Hal. 431

7 lbid Hal. 433

8 Karim, Adiwarman A. Ekonomi Mikro Islam Edisi 4, PT. RajaGrafindo Persada Jakarta. 2011 hal 62
}

Agus Tomi 


\section{AT TAAJIIR}

Vol. 1, No. 1, (2019)

ISSN : 2685-435X

Juli - Desember

E-ISSN :

Menurut Al-Ghazali, kesejahteraan (maslahah) dari suatu masyarakat tergantung kepada pencarian dan pemeliharaan lim atujuan dasar, yaitu agama (ad-dien), hidup atau jiwa (nafs), keluarga atau keturunan (nasl), harta atau kekayaan (maal), dan intelek atau akal (aql). la menitikberatkan bahwa sesuai tuntutan wahyu, "kebaikan dunia ini dan akhirat (maslahat ad-din wa al-dunya) merupakan tujuan utamanya. ${ }^{9}$

Al-Ghazali mendefinisikan aspek ekonomi dari fungsi kesejahteraan sosialnya dalam kerangka sebuah hierarki utilitas individu dan sosial yang tripartit, meliputi kebutuhan (daruriat), kesenangan atau kenyamanan (hajaat), dan kemewahan (tahsinaat), sebuah klasifikasi peninggalan tradisi Aristotelian yang disebut sebagai kebutuhan ordinal (kebutuhan dasar, kebutuhan terhadap barang-barang eksternal, dan terhadap barang-barang psikis). ${ }^{10}$

Walaupun keselamatan merupakan tujuan akhir, Al-Ghazali tidak ingin bila pencarian keselamatan ini sampai mengabaikan kewajiban-kewajiban duniawi seseorang. Bahkan pencarian kegiatan-kegiatan ekonomi bukan saja diinginkan, tetapi merupakan keharusan bila ingin mencapai keselamatan. ${ }^{11}$

\section{Fungsi Utilitas}

Utility (utilitas) adalah rasa kesenangan atau kepuasan yang muncul dari konsumsi, ini merupakan kemampuan memuaskan keinginan atas barang, jasa dari suatu aktivitas.

Berdasarkan utulitasnya, konsumen memiliki berbagai cara dalam memutuskan berapa jumlah barang dan jasa yang akan dibeli dalam berbagai situasi. Ada 2 pendekatan yang dilakukan konsumen, yaitu pendekatan Cardinal /Margina

Utility dan pendekatan Ordinal / Analisis Kurva Indiference /Ordinal utility. Tujuan konsumen adalah memaksimalkan utilitas dengan batasan berupa pendapatan dan harga yang bersangkutan.

Tingkat kepuasan biasanya digambarkan oleh kurva inndeferen yang biasanya digambarkan dalam fungsi utility antara dua barang atau jasa yang keduanya disukai oleh konsumen.

Teori utility function (fungsi utiliti) digunakan tiga aksioma pilihan rasional yaitu; completeness aksioma ini mengatakan bahwa setiap individu selalu dapat menentukan keadaan mana yang lebih disukainya di antara dua keadaan, bila A dan B adalah dua keadaan yang berbeda, maka individu selalu dapat menentukan secara tepat satu di antara tiga kemungkinan. Transitivity aksioma ini menjelaskan bahwa jika seorang individu mengatakan $A$ lebih disukai daripada $B$ dan $B$ lebih disukai daripada $C$, maka ia pasti akan mengatakan bahwa $A$ lebih diisukai daripada $\mathrm{C}$, ini sebenarnya untuk memastikan adanya konsistensii internal di dalam diri individu dalam mengambil keputusan. Continuity aksioma ini menjelaskan bahwa seseorang individu mengatakan $\mathrm{A}$ lebih

\footnotetext{
${ }^{9}$ Abu Hamid Al-Ghozali, Ihya Ulumuddin, (Beirut, Dar An-Nahdah t.t) Jilid 2. Hal 109

10 Lowry S. Todd. The Acheology of Economic Ideas: The Classical Greek Tradition, (Durham: Duke University Press. 1987). Hal. 220

11 Abu Hamid Al-Ghozali, op.cit., Jilid 2 hal. 60
} 


\section{AT TAAJIIR}

Vol. 1, No. 1, (2019)

ISSN : 2685-435X

Juli - Desember

E-ISSN :

disukai daripada B, maka keadaan yang mendekati A pasti juga lebih disukai daripada B. Ketiga aksioma ini dapat diterjemahkan ke dalam bentuk geometris yang sering disebut dengan kurva indiferen. ${ }^{12}$

\section{Fungsi Utilitas}

Dalam ilmu ekonomi tingkat kepuasan (utility function) digambarkan oleh kurva indiferen (indifference curve). Biasanya yang digambarkan adalah utility function antara dua barang (atau jasa) yang keduanya memang disukai oleh konsumen.

Dalam membangun teori utility function, digunakan tiga aksioma pilihan rasional :

\section{Completeness}

Aksioma ini mengatakan bahwa setiap individu selalu dapat menentukan keadaan mana yang lebih disukainya diantara dua keadaan

Transitivity

Aksioma ini untuk memastikan adanya konsistensi internal dalam diri individu dalam mengambil keputusan

Continuity

Aksioma ini menjelaskan bahwa jika seseorang individu mengatakan "A lebih disukai daripada B", maka keadaan yang mendekati A pasti juga lebih disukai daripada B

Ketiga asumsi ini dapat kita terjemahkan ke dalam bentuk geometris yang selanjutnya lebih sering kita kenal dengan kurva indiferen (IC). IC adalah sebuah kurva yang melambangkan tingkat kepuasan konstan, atau sebagai tempat kedudukan masing-masing titik yang melambangkan kombinasi dua macam komoditas (atau berbagai macam komoditas) yang memberikan tingkat kepuasan yang sama. ${ }^{13}$

\section{Barang Halal, Haram dan Analisis Kurva Indiferen}

Tidak semua komoditas mempunyai sifat yang sama, yakni ada yang haram dan ada yang halal, maka kita tidak dapat memberikan pengertian yang sama terhadap bentuk dan fungsi dari kurva indiferen. Kurva indiferen dan garis anggaran digunakan untuk menganalisis pilihan seorang konsumen atas dua macam komoditas. Kesejahteraan konsumen akan meningkat jika ia mengkonsumsi lebih banyak barang yang bermanfaat, halal dan mengurangi mengkonsumsi barang yang buruk atau haram. Dalam Islam sudah cukup rinci mengklasifikasikan mana barang halal dan mana barang buruk. Islam juga melarang untuk menghalalkan apa yang sudah ditetapkan haram dan mengharamkan apa-apa yang sudah ditetapkan menjadi halal.

"Hai orang-orang yang beriman, janganlah kamu mengharamkan apa-apa yang baik yang telah Allah halalkan bagi kamu, dan janganlah kamu melampaui batas. Dan makanlah yang halal lagi baik dari apa yang Allah telah rezekikan kepadamu, dan bertaqwalah kepada Allah yang kamu beriman kepada-Nya." (QS AlMaidah:87-88)

\footnotetext{
12 Karim, Adiwarman A, Ekonomi Mikro Islam Edisi 4, PT. Rajgrafindo Persada. Jakarta 2011 hal 64

13 Walter Nicholson, Microeconomic Theory: Basic Principles and Extensions $6^{\text {th }}$ ed. (New York The Dryden Press. 1995).
} 


\section{AT TAAJIIR}

Vol. 1, No. 1, (2019)

ISSN : 2685-435X

Juli - Desember

E-ISSN :

Untuk menerangkan bagaiman akurva indiferen dibentuk dari berbagai komoditas yang telah memisahkan antara halal dan haram dari komoditas dapat kita lihat dari gambar di bawah ini.

\section{Increasing Utility}

Semakin tinggi kurva indiferen berarti semakin banyak barang-barang yang dapat dikonsumsi, yang berarti semakin tinggi tingkat kepuasan konsumen. Secara grafis tingkat utilitas yang lebih tinggi digambarkan dengan utility function yang letaknya di sebelah kanan atas. Bagi konsumen, semakin ke kanan atas utility function semakin baik. Bentuk utility function yang konveks menunjukkan adanya diminishing marginal rate of substitution.

Dalam Islam cara pikir ini juga ditemukan. Rasulullah SAW bersabda : "Orang beriman yang kuat lebih baik dan lebih dicintai daripada orang beriman yang lemah."

Dalam hadis lain bermakna : "iri hati itu dilarang kecuali terhadap dua jenis orang, yaitu orang berilmu yang mengamalkan dan mengajarkan ilmunya, dan orang yang kaya dan membelanjakan hartanya di jalan Allah."

Jadi dalam konsep Islam pun diakui bahwa yang lebih banyak (tentunya yang halal) lebih baik.

Dalam konsep Islam sangat penting adanya pembagian jenis barang (atau jasa) antara yang haram dan yang halal. Oleh karena itu, sangat penting bagi kita untuk menggambarkan hal ini dalam utility function. Utility function untuk dua barang yang salah satunya tidak disukai digambarkan dengan utility function yang terbalik seakan diletakkan cermin. ${ }^{14}$ Semakin sedikit barang yang tidak kita sukai memberikan tingkat kepuasan yang lebih tinggi. Hal ini digambarkan dengan utility function yang semakin ke kiri atas semakin tinggi tingkat kepuasannya. Barang yang haram adalah barang yang tidak kita sukai.

Semakin banyak barang yang halal berarti menambah utility sedangkan semakin sedikit barang yang haram berarti mengurangi disutility. Keadaan ini akan memberikan tingkat kepuasan yang lebih tinggi.

\section{Budget Costrain}

Segala keinginan pasti ada kostrain yang membatasinya, tentu batasan ini akan sangat dipengaruhi oleh kemampuan dan usaha yang dikeluarkan untuk mendapatkan kostrain yang lebih tinggi. Rasulullah SAW pernah menggambarkan hubungan antara cita-cita atau keinginan manusia dan segala hambatan yang mesti dijumpainya. Untuk menjelaskan bagaimana seorang mukmin berusaha meraih cita-citanya ia membuat gambar empat persegi panjang. Di tengah-tengah ditarik satu garis sampai keluar. Kemudian beliau membuat garis pendek-pendek di sebelah garis yang di tengah-tengah seraya berkata :

"Ini adalah manusia dan empat persegi panjang yang mengelilinginya adalah ajal. Garis yang di luar ini adalah cita-citanya, serta garis yang pendek-pendek adalah hambatan-hambatannya. Apabila ia dapat menghadapi hambatan yang satu, maka ia akan menghadapi hambatan yang lain. Dan apabila ia dapat mengatasi hambatan yang lain, maka ia akan menghadapi hambatan lain lagi."

\footnotetext{
${ }^{14}$ Robert H. Frank op.cit.
} 


\section{AT TAAJIIR}

Vol. 1, No. 1, (2019)

ISSN : 2685-435X

Juli - Desember

E-ISSN :

Untuk tetap bersemangat melangkah dari setiap hambatannya tersebut, maka ia mengembalikan sepenuhnya kepada Allah SWT, ia percaya bahwa tiada sesuatu yang terjadi di alam ini tak lain atas kehendak Allah.

Dalam teori konsumsi, hadist tentang cita-cita dan segala macam hambatan ini bisa kita gunakan untuk menerangkan tentang batasan seseorang dalam memaksimalkan utility konsumsinya. Selain faktor norma konsumsi dalam Islam, keinginan untuk memaksimalkan utility function ditentukan juga oleh berapa dana yang tersedia untuk membeli kedua jenis barang tersebut. Batasan ini disebut budget costraint. ${ }^{15}$

\section{Solusi Optimal}

Sesuai dengan asumsi rasionalitas, maka konsumsi seorang muslim akan selalu bertindak rasional. Oleh sebab itu pengambilan keputusan dari seorang konsumen senantiasa didasarkan pada perbandingan antar berbagai preferensi, peluang, dan manfaat serta mudharat yang ada. Konsumen yang rasional selalu berusaha menggapai preferensi tertinggi dari segenap peluang dan manfaat yang tersedia. Konsumen yang rasional berarti konsumen yang memilih suatu kombinasi komoditi yang akan memberikan tingkat utilitas paling besar. Utilitas disini juga meliputi maslahat dan mudharat yang ditimbulkan dari mengkonsumsi komoditas tersebut. ${ }^{16}$

\section{KESIMPULAN}

Kepuasan dalam ekonomi Islam memiliki pandangan dan pemaknaan yang lebih komprehensip jika dibandingkan dengan konsep kepuasan konvensional, dimana dalam ekonomi Islam kepuasan tidak hanya untuk memenuhi kebutuhan dan keinginan untuk mencapai kemaslahatan bersama (kesejahteraan masyarakat) tetapi bermuara pada ketaatan sebagai mahluk ciptaan Tuhan yang didasari oleh nilai-nilai ideologi Islam. Sedangkan dalam pandangan konvensional bahwa kepuasan itu setiap individu selalu dapat menentukan keadaan mana yang lebih disukainya di antara dua keadaan atau lebih (completness) tanpa memandang maslahat dan mudharatnya. Jelaslah bahwa keinginan manusia untuk mengumpulkan kekayaan, tetapi juga kebutuhannya untuk persiapan dimasa depan, dengan demikian bahwa jika semangat selalu ingin lebih ini akan menjurus kepada keserakahan dan pengejaran nafsu pribadi, maka hal ini memandang kekayaan sebagai "ujian terbesar".

Dalam Pandangan Islam bahwa setiap individu harus bertanggungjawab untuk bekerja dan memastikan setiap sumber pendapatan dan kekayaan diperoleh dari cara yang halal menurut aturan Islam.

\section{DAFTAR PUSTAKA}

Al-Qur'an dan Terjemahan Departemen Agama RI. PT Syamil Cipta Media. 2005

Al Qaradhawi. Y. Ekonomi Islam Nilai dan Akhlak. KL: YaPEIM. 2009

Aziz Farooq, Abbas H, Aqil M, Bhutto SA. Economic Man Vs Islamic Man. Interdisciplinary Journal Of Contemporary Reserch In Business. Vol 3 No.2. 2011

\footnotetext{
${ }^{15}$ Karim, Adiwarman K, Ekonomi Mikro Islam, Edisi 4, PT RajaGrafindo Persada, Jakarta 2012 Hal. 71

16 Ibid hal. 72
}

Agus Tomi 


\section{AT TAAJIIR}

Vol. 1, No. 1, (2019)

ISSN : 2685-435X

Juli - Desember

\section{E-ISSN :}

Cholxon Walter \& Snyder Cristopher. Microeconomic Theory basic Principle and Extension $10^{\text {th }}$ Edition. Thomson South Western. 2008

Joko Susilo, Analisis Maslahah Pemikiran Al-Ghozali dan Relevansinya terhadap Ekonomi Kontemporer, Tesis

Ekonomi Islam, IAIN Sunan Ampel, 2001

Gofal et al, Economic Theory, Goverment of Amilnadu. 2007

Karim, Adiwarman A. Ekonomi Mikro Islam Edisi 4, PT RajaGrafindo Persada Jakarta. 2011

Karim Abdul (2006).Defining Islamic Man, Daily Dawn. June 09

Rittenberg Libby. Principles of Microeconomic

Rivai Veithzal, Buchori Andi. Islamic Economics. Ekonomi Syariah Bukan OPSI. Tetapi Solusi. Bumi Aksara. 2009.

Smith Adam (1986). On The Division of Labour The Wealth Of Nations. Books I - III New York P.119

Walter Nicholson. Microeconomic Theory Basic Principles and Exetensions $6^{\text {th }}$ ed.(New York Dryden Prss. 1995). 